UDC 621.313.32. 045.53:621. 314.6

\title{
12 パルス整流器負荷三相二重巻線同期機
}

\begin{tabular}{|lr|}
\hline 論 文 \\
\hline $55-B 29$ \\
\hline
\end{tabular}

\author{
正員松 本 久男 (新居浜工専) \\ 正員稲 見和生 (新居浜工専)
}

\section{1. まえがき}

誘導電動機の巻線を三相三重構成にして，とれを電 王形および電流形九相インバータで駆動する場合，小 容量の結合リアクトルにより 3 組の三相巻線電流の平 衡が得られるばかりでなく，その波形が改善されるこ

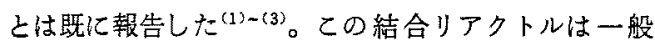
に三相 $N$ 重 $(N \geqq 2)$ 構成の交流回路の電流平衡と波 形改善に有效であり，とれを適用した三相二重巻線同 期機之 2 組の三相ブリッジ整流器を組合せた掲題の装 置の多軸行列法 ${ }^{(4)}$ 亿よる特性解析の概要と波形改善の

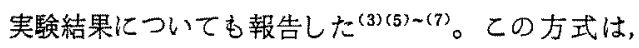
大容量装置の特性改善に特汇有用と考元られる。

大容量 6 パルス整流器負荷同期発電機の一例とし て, 電解工業用の直流電源として整流器皘載同期発電 機が実用されている(8)。乙の装置では，交流電流に多 量の高調波成分を含むため，発電機の制動巻線設計な どに特別な考慮が必要である(8)。また，大電流容量を 得るためには，整流素子の並列使用が避けられない。 ここで報告する方式では，小容量の結合リアクトルが 必要であるが, 変王器を省略して 12 パルス整流装置 が構成できて，交流電流の高調波成分が大幅に減少し て発電機の設計が容易になり, 整流素子の並列数も半 減する。更に，後述するように沽置の諸特性も改善さ れるので，本方式の採用を有利上することが考えられ る。

本装置を逆変換動作領域で運転すると，無整流子電 動機になる。トルク眽動を小さくして直流機に近い高 度な速度制御特性を得るための無整流子電動機として 電動機巻線を三相二重にして 2 組の三相ブリッジィン バータを使用する点では本装置之同㥞な方式が実用さ れている(9)。両方式とも，トルク脈動を減少させる原

\footnotetext{
Double Three-Phase Wound Synchronous Machines with Twelve-Pulse Rectifier Load. By Hisao Matsumoto, Member \& Kazuo Inami, Member (Electrical Engineering Department of Nithama Technical College) 松本久男 : 正貣, 新居捠工釆高等尃門学校電気工学科 啝見和生 : 正是, 新居捠工亲高等専門学校電気工学科
}

理は同一であるが，本方式では相電流の第 5 および 第 7 調波成分が除去され，文献(9)の方式では，これ が除去されない。また，同期機の諸定数と特性との関 連を明確に表現する解析式は得られていないようであ る(9)。上述の調波成分は, 電動機内部では相殺する起 磁力を発生するむのであって，トルク発生には無関係 であり，乙れの除去により，装置の損失が減少し，転 流が容易になると考えられる。

本方式は従来の 6 パルス方式と比較して，トルク脈 動が減少するばかりでなく, 直流回路電纴の脈動が減 少するので平滑リアクトルの小容量化が可能になり， 無整流子電動機として高度な速度制御特性を得るのに 特に適当すると考えられるが，無整流子電動機として の詳細な特性検討は次の課題として,こてでは,同期僟 の諸定数と特性との関連を明確に表現して，諸特性の 体系的な把握を可能にする解式の提供を主体として, 回路構成と動作原理，ならびに実験結果をまとめて報 告し既に報告した 6 パルス整流器目荷三相同期機の解 析 ${ }^{(10)}$ と比較して, 本方式による基本的な諸特性の改善 を明らかにする。

\section{2. 回路構成とその動作}

第 1 図にこの装置の主回路を示す。図において発電 譏は中点が $O_{1}$ および $O_{2}$ である $U_{1}, V_{1}, W_{1}$ およ び $U_{2}, V_{2}, W_{2}$ 巻線よりなる二つの星形巻線を持つ。 との 2 組の星形巻線の起電力が, $\pi / 6$ の位相差を持つ ように構成している。従って, 電流む同じ位相差にな る。2 組の相電流 ( $i_{u 1}$ などと $i_{u 2}$ など) はそれぞれ三 相結合リアクトルを介して2 組の三相ブリッジ結線の 整流器 (Rec. 1 亡Rec. 2) 亿供給されて全波整流され その出力電流 $i_{L 1}$ と $i_{L 2}$ の和 $I_{L}$ が, 平滑リアクトル $X_{L}$ を介して負荷に供給される。

磁路に空げきを持たない，三相結合リアクトルの各 脚 $\left(M_{u}, M_{v}, M_{w}\right)$ の巻線は，それぞれ 2 組の星形巻線の 電流の基本波成分による起磁力の和が雾になるように 巻かれている。例えば $M_{u}$ においては， $n$ 巻の巻線 $N_{u 1}$ には $i_{u 1}$ を, $n / \sqrt{3}$ 巻の巻線 $N_{v 22}$ と $N_{u 21}$ には 


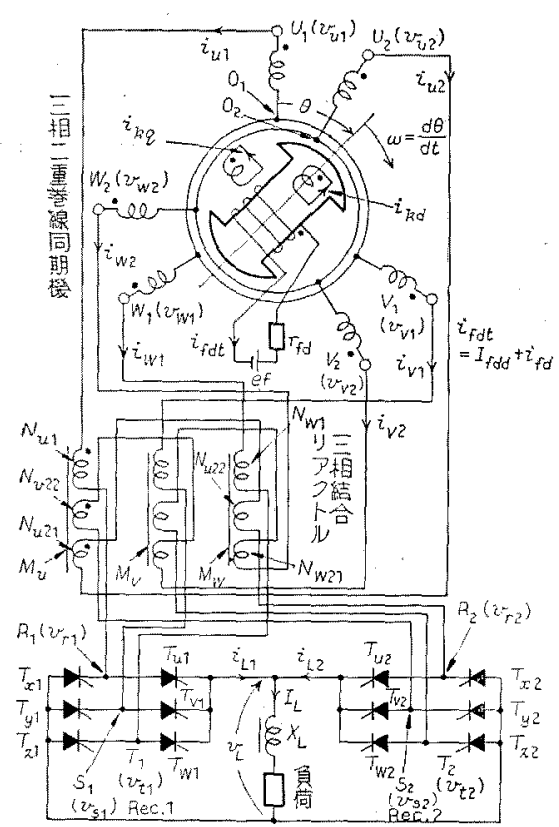

第 1 图 12 パルス整流器負荷三相二重巻線 同期機の回路

Fig. 1. Circuit diagram of double threephase wound synchronous machine with twelve-pulse rectifier load.

$i_{v 2}$ と $i_{42}$ を四の極性で流す。このようにすると，各 相の電流の基本波成分か平衡するばかりでなく, 結合 リアクトルの第 5 拈よび第 7 調波電流による起磁力の 和は零にならないので，相電流より第 5 および第 7 調 波成分が除去される(5)。

\section{3. 基 礎 式}

$\langle 3.1\rangle$ 同期機電圧方程式 同期機の直軸之横軸 の制勳巻線は互いに，独立に分布巻汇なっていて，そ の高謂波電流に対する抵抗の增加を無視するものとす る。また，磁路の飽和および空間高調波の影響を無視 し，界磁は一定の電気角速度 $\omega て ゙$ 回転するものとす る。電機子 $U_{1}$ 相の巻線軸を基準にとって界磁の電気 回転角を $\theta(=\omega t)$ とし， $P_{\theta}=d / d \theta$ として電圧方程式 を立て，瞬時値対称座標法比上る变換行列

$$
\left[\dot{A}_{\beta}\right]=(1 / \sqrt{12})\left(\dot{b}_{\lambda \xi}\right]
$$

但し，

$$
\begin{aligned}
& \dot{b}_{\lambda \xi}=\dot{\beta}^{(\lambda-1)(\xi-1)}(\lambda, \xi=1,2, \cdots \cdots, 12) \\
& \dot{\beta}=\varepsilon^{j \pi / 6}
\end{aligned}
$$

汇より変換を施せば，次の基礎方程式が得られる(7)。 $\dot{V}_{1}=-\left(r_{a}+x_{l} p_{\theta}\right) \dot{I}_{1}-(3 / 2)\left(x_{a d}\right.$

$$
\left.+x_{a q}\right) P_{\theta} \dot{I}_{1}-(3 / 2)\left(x_{a d}-x_{a q}\right) P_{\theta} \dot{I}_{2} \varepsilon^{2 j \theta}
$$

$$
\begin{aligned}
& +\sqrt{3} x_{a f d} P_{\theta i} i_{f d t} \varepsilon^{j \theta} \\
& +\sqrt{3} x_{a k d} P_{\theta} i_{k d} \varepsilon^{j \theta} \\
& -j \sqrt{3} x_{a k q} P_{\theta} i_{k q} \varepsilon^{j \theta} \text {. } \\
& \dot{V}_{5}=-\left(r_{a}+x_{l} P_{\theta}\right) \dot{I}_{5}-2 x_{c} P_{\theta} \dot{I}_{5} \\
& e_{f}=\left(r_{f d}+x_{f d} P_{\theta}\right) i_{f d t} \\
& -\sqrt{3} x_{a f d} P_{\theta} R_{e}\left(\dot{I}_{1} \varepsilon^{-j \theta}\right)+x_{f k d} P_{\theta i} i_{k d} \\
& 0=\left(r_{k d}+x_{k d} P_{\theta}\right) i_{k d} \\
& -\sqrt{3} x_{a k d} P_{\theta} R_{e}\left(\dot{I}_{1} \varepsilon^{-j \theta}\right)+x_{f k d} P_{\theta} i_{f d t} \\
& 0=\left(r_{k q}+x_{k q} P_{\theta}\right) i_{k q} \\
& -\sqrt{3} x_{a k q} P_{\theta} R_{e}\left(j \dot{I}_{1} \varepsilon^{-j \theta}\right) \\
& \dot{V}_{7}=\dot{V}_{5}^{*}, \dot{V}_{11}=\dot{V}_{1} * ; \dot{I}_{7}=\dot{I}_{5} *, \dot{I}_{11}=\dot{I}_{1} * ; \\
& \dot{V}_{i}, \dot{I}_{i}(i \neq 1,5,7,11)=0
\end{aligned}
$$

ここで，米四は共役複素数を，Re(）は複素数の㬰部 を示す。( 淂で転置行列を表示して， $\dot{V}_{1}, \dot{I}_{1} な と ゙$ は 第 1 図の Rec. 1 とRec. 2 の相電压 (中点 $O_{1}$ と $O_{2}$ に対する $R_{1}$ 点などと $R_{2}$ 点などの電生) $v_{r 1}, v_{r 2}$ お よび相電流 $i_{u 1}, i_{u 2}$ などで要素間位相差 $\pi / 6$ 亿構成し たベクトルを次式のように変換したるのである。

$$
\begin{aligned}
{\left[\dot{V}_{0},\right.} & \left.\dot{V}_{1}, \cdots \cdots, \dot{V}_{11}\right]^{T} \\
= & {\left[\dot{A}_{\beta}\right]\left[v_{r 1}, v_{r 2},-v_{t 1},-v_{t 2}, v_{s 1}, v_{s 2},\right.} \\
& \left.\quad-v_{r 1},-v_{r 2}, v_{t 1}, v_{t 2},-v_{s 1},-v_{s 2}\right]^{T} \\
{\left[\dot{I}_{0}, \dot{I}_{1}, \cdots \cdots, \dot{I}_{11}\right]^{T} } & \\
= & {\left[\dot{A}_{\beta}\right]\left[i_{u 1}, i_{u 2},-i_{w 1},-i_{w 2}, i_{v 1}, i_{v 2}\right.} \\
& \left.\quad-i_{u 1},-i_{u 2}, i_{w 1}, i_{w 2},-i_{v 1},-i_{v 2}\right]^{T}
\end{aligned}
$$

また，添字付き $r, x$ は抵抗および自己・相互りアク タンスを示して, 添字 $a, f, k$ が電機子卷稳の1相， 界磁巻線，制動巻線を意味し， $d, q$ が直軸，横軸成 分を意味する。 $x_{a f d}$ などの相互リアクタンスは両巻 線が同軸時の最大值を示し， $x_{1}$ は電機子 1 相分の漏れ リアクタンスを示す。 $e_{f}$ と $i_{f d t}$ は界磁電正之電流で あり， $i_{k q}$ 上 $i_{k q}$ は直軸と横軸の制勤巻線電流である。 なお，三相結合リアクトルの巻線間の結合係数を 1 と して， $N_{u 1}$ など $n$ 巻の巻線の自己りアクタンスを $x_{c}$ とした。

前迄したように，結合リアクトルの鉄心は空げきを 含まず $x_{\varepsilon}$ が非常に大きいので; (3)式は第 1 項が第 2 項に比べて無視できるすのになって， $x_{c}$ のみの項に なる。また（2）式估 $x_{0}$ の項を含まない。従って， (2)式の $\dot{V}_{1}$ は同期機の相電生 (中点 $O_{1}$ 之 $O_{2}$ 江対

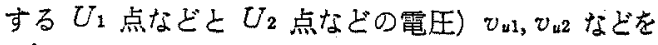
$\left[\dot{A}_{\theta}\right]$ で変換したものになり，(3)式の $\dot{V}_{5}$ は結合り 
アクトルによる $U_{1}, U_{2}$ 相などの電圧降下 $v_{n u 1}$ (巻線 $N_{u 1}$ の $U_{1}$ 点汇対する $R_{1}$ 点の電圧を $v_{n u 1}$ 之表示す

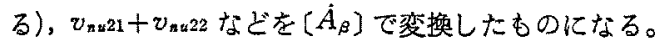
すなわち, Rec. 1 と Rec. 2 の相電压 $v_{r 1}, v_{r 2}$ などの 瞬時值正, 逆相分 $\dot{V}_{1}, \dot{V}_{11}\left(=\dot{V}_{1} *\right)$ 以外の電圧成分 $\dot{V}_{5}$, $\dot{V}_{7}\left(=\dot{V}_{5}^{*}\right)$ は，結合リアクトルに吸収されることにな る。なお，(2)式において，第 3 項は突極効果を示し 第 4 項は界磁による起電力を示す。(4)〜 (6) 式の第 2 項は平衡基本波相電流住対しては零となり，電機子 電流の高調波成分により誘起される電圧を示す。

交流分に対する各巻線の抵抗老無視し， $i_{f d t}$ の直流

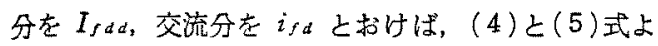

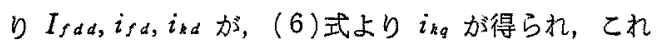

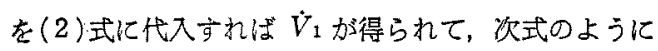
なる。

$$
\begin{aligned}
& \dot{V}_{1}=-(1 / 2)\left(x_{d}^{\prime \prime}+x_{q}^{\prime \prime}\right) P_{\theta}\left(\dot{I}_{1}+\mu \dot{I}_{1} * \varepsilon^{2 j \theta}\right) \\
& +j \sqrt{3} x_{\alpha f d} I_{f d d} \varepsilon^{j \theta} \\
& +j \sqrt{3}\left(x_{a f d} I_{f d}+x_{a k d} I_{k d}\right) \varepsilon^{j \theta} \\
& +\sqrt{3} x_{a k_{q}} I_{k q} \varepsilon^{j \theta} \\
& \dot{V}_{5}=-2 x_{c} P_{\theta} \dot{I}_{5} \\
& e_{f}=r_{f d} I_{f d d}, \quad i_{f d t}=I_{f d d}+i_{f d} \\
& i_{f d}=I_{f d}+\sqrt{3} K_{f d} R_{e}\left(\dot{I}_{1} \varepsilon^{-j \theta}\right) \\
& i_{k d}=I_{k d}+\sqrt{3} K_{k d} R_{e}\left(\dot{I}_{1} \varepsilon^{-j \theta}\right) \\
& \left.i_{k q}=I_{k q}+\sqrt{3} K_{k q} R_{e}\left(j \dot{I}_{1} \varepsilon^{-j \theta}\right)\right)
\end{aligned}
$$

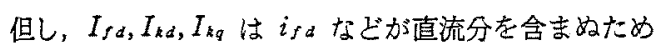
の定数項であり，

$$
\begin{aligned}
& x_{d}^{\prime \prime}=x_{l}+3\left(x_{a d}-X_{k d}\right) \\
& x_{q}^{\prime \prime}=x_{1}+3\left(x_{a q}-X_{k q}\right) \\
& \mu=\left(x_{d}^{\prime \prime}-x_{q}^{\prime \prime}\right) /\left(x_{d}^{\prime \prime}+x_{q}^{\prime \prime}\right) \\
& X_{k d}=K_{f d} x_{a f d}+K_{k d} x_{a k d} \\
& X_{k q}=K_{k q} x_{a k q} \\
& K_{f d}=\left(1-\frac{x_{f k d}{ }^{2}}{x_{f d} x_{k d}}\right)^{-1}\left(\frac{x_{a f d}}{x_{f d}}-\frac{x_{f k d} x_{a k d}}{x_{f d} x_{k d}}\right) \\
& K_{k d}=\left(1-\frac{x_{f k d}{ }^{2}}{x_{f d} x_{k d}}\right)^{-1}\left(\frac{x_{a k d}}{x_{k d}}-\frac{x_{f k d} x_{a f d}}{x_{f d} x_{k d}}\right) \\
& K_{k q}=x_{a k q} / x_{k q}
\end{aligned}
$$

上式の $x_{d}{ }^{\prime \prime}, x_{q}{ }^{\prime \prime}$ は直軸，横軸の初期過渡リアクタ ンス（多相定数）として作用するもので， $\mu$ は突極構 造上制動巻線効果の相異に起因する両者の差を示す係 数である。平衡基本波相電流に対しては，(12)式の第 2 項が定数となることより，交流電流である $i_{f d}$ など が零になることがわかる。

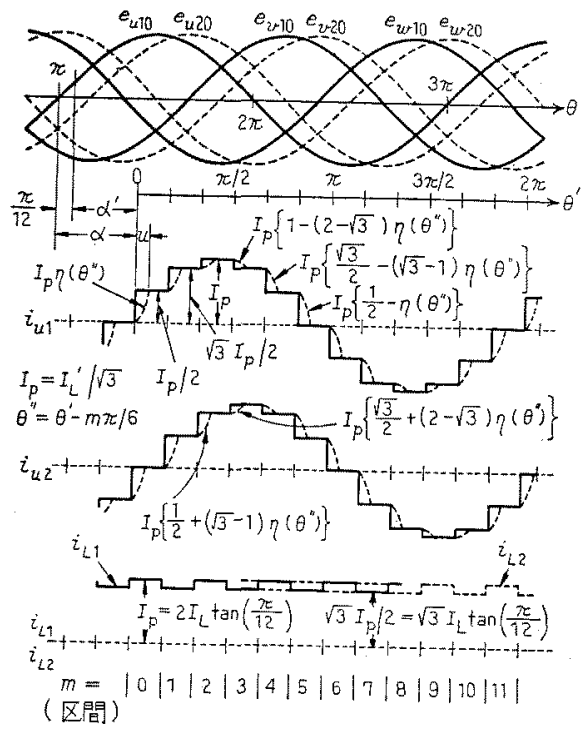

第 2 図 無負荷相誘導起電力と相電流の関係 Fig. 2. Relations between no-load phase induced emfs and phase currents.

\section{〈3.2〉回路条件により規定される電圧, 電流式}

第1 図の平滑りアクトル $X_{L}$ が十分大きく負荷電流 $I_{L}$ が平滑であるとし, サイリスタ $T_{u 1}, T_{x 1}$ などの順 方向電圧降下を無視する。

$i_{f d t}=I_{f d d}$ 亿なる無負荷時の $U_{1}$ 相誘導起電力 $e_{u 10}$ $=x_{a f d} P_{\theta} I_{f d d} \cos \theta=x_{a f d} I_{f d d} \sin (\theta+\pi) の \theta=\pi+\alpha$ の時点にサイリスタ $T_{u 1}$ が点弧されて $i_{u 1}$ が正方向に 通電を始めるものとする。との時点を原点とする電気 角を $\theta^{\prime}$ とし, 同期機内の電磁現象が $\pi / 6$ 刻みに同様 の変化を繰返すので， $\theta^{\prime}$ を次式のように表し，第 2 図 のように区間分けする。

$$
\begin{aligned}
& \theta^{\prime}=\theta-(\pi+\alpha)=m \pi / 6+\theta^{\prime \prime} \\
& \quad\left(m=0,1,2, \cdots \cdots ; 0<\theta^{\prime \prime}<\pi / 6\right) . .
\end{aligned}
$$

第 1 図の結合リアクトルは, 前述したように空げき なしの鉄心でできているので，その励磁電流が非常に 小さくなり，各区間汇拉いて次式の関係が成立する。

$$
\left.\begin{array}{l}
i_{u 1}+(1 / \sqrt{3})\left(i_{v 2}-i_{u 2}\right) \fallingdotseq 0 \\
i_{v 1}+(1 / \sqrt{3})\left(i_{w 2}-i_{v 2}\right) \fallingdotseq 0 \\
i_{w 1}+(1 / \sqrt{3})\left(i_{u 2}-i_{w 2}\right) \fallingdotseq 0
\end{array}\right\}
$$

この関係と $i_{u 1}+i_{t 1}+i_{w 1}=0$ および $i_{u 2}+i_{v 2}+i_{w 2}=0$ の関係を用い，更に，相電流相互の位相関係と $I_{L}$ か 平滑である条件を用いて計算すると，転流加瞬時に完 了するとした場合，相電流は第 2 図の実線で示すよう になる。ここでは，以後の式表現を簡単にするために $I_{L}^{\prime}$ を次式のように定義している。 


$$
I_{L}^{\prime}=2 \sqrt{3} I_{L} \tan (\pi / 12)
$$

このとき相電流の最大值 $I_{p}$ は $I_{p}=I_{L}^{\prime} / \sqrt{3}$ になる。

次に，点線で示すように転流現象を考慮した相電流 考える。相電流が重なる転流期間を uとし，乙の 期間中に零加ら図説の $I_{p} / 2$ まで変化する相電流（例 えば, $m=0$ の区間の $\left.i_{u 1}\right)$ を $I_{p} \eta\left(\theta^{\prime \prime}\right)$ で表わすと， 転流時の各相の電流が図に記入したように算出され， 次式分成立する。

$$
\left.\begin{array}{l}
\eta(0)=0, \quad \eta(u)=1 / 2 \\
\eta\left(\theta^{\prime \prime}\right)=1 / 2\left(u<\theta^{\prime \prime}<\pi / 6\right)
\end{array}\right\}
$$

また，各区間で転流期間中は導通していて転流完了 後逆電纴を受けるサイリスタの電压を $v_{x}\left(\theta^{\prime \prime}\right)$ で表わ すと，次式が成立する。

$$
v_{x}\left(\theta^{\prime \prime}\right)=0\left(0<\theta^{\prime \prime}<u\right)
$$

以上より各区間での相電流を $I_{L}$ よ $\eta$ で表し, 結 合リアクトルを含む相電瓜 $v_{r 1}, v_{r 2}$ などを負荷電王 $v_{L}\left(\theta^{\prime \prime}\right)$ と $v_{x}\left(\theta^{\prime \prime}\right)$ を用いて求めて，(8)式の変换によ り $\dot{I}_{1}, \dot{I}_{5}, \dot{V}_{1}$ 书よび $\dot{V}_{5}$ を求めると，次式が得られる。

$$
\begin{aligned}
& \dot{V}_{1}=(1 / V \overline{3}) \dot{\beta}^{-5 / 2}\left\{\left\{2 v_{L}\left(\theta^{\prime \prime}\right) \cos (\pi / 12)\right.\right. \\
& \left.+\dot{\beta}^{3 / 2} v_{x}\left(\theta^{\prime \prime}\right)\right\} \dot{\beta}^{m} \\
& \dot{I}_{1}=-j I_{L^{\prime}}\left\{1+\dot{\beta}^{7 / 2} \eta^{\prime}\left(\theta^{\prime \prime}\right)\right\} \dot{\beta}^{m} \\
& \dot{V}_{5}=(1 / V \overline{3}) \dot{\beta}^{-1 / 2}\left\{2 v_{L}\left(\theta^{\prime \prime}\right) \sin (\pi / 12)\right. \\
& \left.-\hat{\beta}^{-1 / 2} v_{x}\left(\theta^{\prime \prime}\right)\right\} \dot{\beta}^{5 m} \\
& \dot{I}_{5} \fallingdotseq 0
\end{aligned}
$$

但L，

$$
\eta^{\prime}\left(\theta^{\prime \prime}\right)=4 \eta\left(\theta^{\prime \prime}\right) \sin (\pi / 12)
$$

また，前述したように $\dot{V}_{1}$ 沬同期機の相電圧を夋换 したものになり， $\dot{V}_{5}$ は結合リアクトル電王を变換し たものになるので（）式の逆変換に上式を代入して 相電圧，相電流拉よび結合リアクトル電代が次式の上 うに表示される。

$$
\begin{aligned}
v_{u 1}= & \frac{2}{3} v_{L}\left(\theta^{\prime \prime}\right) \cos \frac{\pi}{12} \sin \left\{\left(m+\frac{1}{2}\right) \frac{\pi}{6}\right\} \\
& +(1 / 3) v_{x}\left(\theta^{\prime \prime}\right) \cos \{(m+1) \pi / 6\} \\
i_{u 1}= & (1 / \sqrt{3}) I_{L}^{\prime}[\sin (m \pi / 6) \\
& \left.+\eta^{\prime}\left(\theta^{\prime \prime}\right) \cos \{(m+(1 / 2)) \pi / 6\}\right) \\
v_{n u 1}= & \frac{2}{3} v_{L}\left(\theta^{\prime \prime}\right) \sin \frac{\pi}{12} \cos \left\{\left(5 m-\frac{1}{2}\right) \frac{\pi}{6}\right\} \\
& -(1 / 3) v_{x}\left(\theta^{\prime \prime}\right) \cos \{(5 m-1) \pi / 6\}
\end{aligned}
$$

\section{4. 電圧, 電流解}

(14)式の関係を考慮して，(9)，(12)式に（19），(20) 式を代入し，加第 2 四の各区間で(12) 式の各交流電 流の平均値が零となる条件に(17)式と(23)式の関係を
適用すると，次式が得られる。

$$
\begin{aligned}
& 2 v_{L} \cos (\pi / 12)+j \varepsilon^{j \pi / 12} v_{x} \\
& =-j(\sqrt{3} / 2)\left(x_{a^{\prime \prime}}+x_{q}^{\prime \prime}\right) I_{L}^{\prime}\left(P_{\theta} \eta^{\prime}\right. \\
& \left.+\mu P_{\theta} \eta^{\prime} \varepsilon^{2 j\left(\theta^{\prime \prime}+\alpha^{\prime}\right)}-2 \mu \varepsilon^{2 j\left(\theta^{\prime \prime}+\alpha^{\prime}+\pi / 24\right)}\right) \\
& +3\left(x_{a f^{\prime} d} I_{f d d}+x_{a k d^{\prime}} I_{k d}\right. \\
& \left.-j x_{a k q} I_{k q}\right) \varepsilon^{j\left(\theta^{\prime \prime}+\alpha^{\prime}\right)}
\end{aligned}
$$

$$
\begin{aligned}
& I_{k d}=-\frac{6 \sqrt{3}}{\pi} K_{k d} I_{L^{\prime}} \int_{0}^{u} \sin \left(\theta^{\prime \prime}\right. \\
&\left.+\alpha^{\prime}\right) P_{\theta} \eta^{\prime} d \theta^{\prime \prime} \\
& I_{k q}= \frac{6 \sqrt{3}}{\pi} K_{k q} I_{L^{\prime}} \int_{0}^{u} \cos \left(\theta^{\prime \prime}\right. \\
&\left.+\alpha^{\prime}\right) P_{\theta} \eta^{\prime} d \theta^{\prime \prime} \\
& I_{f d} / I_{k d}=i_{f d} / i_{k d}=K_{f d} / K_{k d}
\end{aligned}
$$

但し， $\alpha^{\prime}=\alpha-\pi / 12$ (第 2 図参照)であり，

$$
x_{a f d} I_{f d}+x_{a k d} I_{k d}=x_{a k d^{\prime}} I_{k d}
$$

次に，(25)式の実数部と虚数部より $v_{L}, v_{x}, \eta^{\prime}$ を求 めてその結果を記す。

（a） 転流期間中 $\left(0<\theta^{\prime \prime}<u\right)$ 乙の期間中は $v=$ =0であり,

$$
\begin{aligned}
\eta^{\prime}= & \mu\left\{\sin 2\left\langle\theta^{\prime \prime}+\alpha^{\prime}+\pi / 24\right)\right. \\
& \left.-\sin 2\left(\alpha^{\prime}+\pi / 24\right)\right\} /\left\{1+\mu \cos 2\left(\theta^{\prime \prime}+\alpha^{\prime}\right)\right\} \\
& +2 \sqrt{3}\left(( x _ { a f d } I _ { f d d } + x _ { a k d ^ { \prime } } I _ { k d } ) \left\{\cos \alpha^{\prime}\right.\right. \\
& \left.-\cos \left(\theta^{\prime \prime}+\alpha^{\prime}\right)\right\}+x_{a k q} I_{k q}\left\{\sin \alpha^{\prime}\right. \\
& \left.\left.-\sin \left(\theta^{\prime \prime}+\alpha^{\prime}\right)\right\}\right] /\left(x_{d^{\prime \prime}}+x_{q}^{\prime \prime}\right) I_{L}^{\prime} \\
& \times\left\{1+\mu \cos 2\left(\theta^{\prime \prime}+\alpha^{\prime}\right)\right\} \ldots \ldots \ldots \ldots(29) \\
v_{L}= & \sqrt{3} \mu\left(x_{d^{\prime \prime}}+x_{q^{\prime \prime}}\right) I_{L^{\prime}}\left[\eta^{\prime}\{\mu\right. \\
& \left.+\cos 2\left(\theta^{\prime \prime}+\alpha^{\prime}\right)\right\}-\sin 2\left(\theta^{\prime \prime}+\alpha^{\prime}\right. \\
& +\pi / 24)-\mu \sin (\pi / 12)] /\{2 \cos (\pi / 12)\} \\
& \times\left\{1+\mu \cos 2\left(\theta^{\prime \prime}+\alpha^{\prime}\right)\right\}+3\{(1+\mu) \\
& \times\left(x_{a f d} I_{f d d d}+x_{a k d^{\prime}} I_{k d}\right) \cos \left(\theta^{\prime \prime}+\alpha^{\prime}\right) \\
& \left.+(1-\mu) x_{a k q} I_{k q} \sin \left(\theta^{\prime \prime}+\alpha^{\prime}\right)\right\} /\{2 \cos \\
& (\pi / 12)\}\left\{1+\mu \cos 2\left(\theta^{\prime \prime}+\alpha^{\prime}\right)\right\} \ldots \ldots .(30)
\end{aligned}
$$

(b) 転流完了後 $\left(u<\theta^{\prime \prime}<\pi / 6\right)$ 乙の期間中は， $\eta^{\prime}=2 \sin (\pi / 12)$ であり,

$$
\begin{aligned}
v_{L}= & \left\{-\sqrt{3} \mu\left(x_{d}^{\prime \prime}+x_{q}^{\prime \prime}\right) I_{L}{ }^{\prime} \sin 2\left(\theta^{\prime \prime}+\alpha^{\prime}\right.\right. \\
& -\pi / 12)\} / 2 \cos ^{2}(\pi / 12)+3\left\{\left(x_{a f d} I_{f d d}\right.\right. \\
& \left.+x_{a k d} I_{k d}\right) \cos \left(\theta^{\prime \prime}+\alpha^{\prime}-\pi / 12\right) \\
& +x_{a k q} I_{k q} \sin \left(\theta^{\prime \prime}+\alpha^{\prime}\right.
\end{aligned}
$$


$-\pi / 12)\} / 2 \cos ^{2}(\pi / 12)$

$v_{x}=\left\{\sqrt{3} \mu\left(x_{d}^{\prime \prime}+x_{q}^{\prime \prime}\right) I_{L}^{\prime} \cos 2\left(\theta^{\prime \prime}+\alpha^{\prime}\right.\right.$

$-\pi / 24)\} / \cos (\pi / 12)+3\left\{\left(x_{a f d} I_{f d d}\right.\right.$

$\left.+x_{a k d^{\prime}} I_{k d}\right) \sin \left(\theta^{\prime \prime}+\alpha^{\prime}\right)-x_{a k q} I_{k q}$

$\left.\times \cos \left(\theta^{\prime \prime}+\alpha^{\prime}\right)\right\} / \cos (\pi / 12)$

両期間の $v_{L}$ の平均値 $\bar{v}_{L}$ は次のようになる。

$$
\begin{aligned}
\bar{v}_{L}= & \{-3 \sqrt{3} \mu \sin (\pi / 12)\}\left(x_{d}^{\prime \prime}+x_{q}^{\prime \prime}\right) I_{L}^{\prime} \\
& \times\left\{\sin 2\left(u+\alpha^{\prime}-\pi / 24\right)+\sin 2\left(\alpha^{\prime}\right.\right. \\
& +\pi / 24)\} / 2 \pi \cos ^{2}(\pi / 12)+\{9 \sin (\pi / 12)\} \\
& \times\left[( x _ { a f d } I _ { f d d } + x _ { a k d ^ { \prime } } I _ { k d } ) \left\{\cos \left(u+\alpha^{\prime}\right)\right.\right. \\
& \left.+\cos \alpha^{\prime}\right\}+x_{a k q} I_{k q}\left\{\sin \left(u+\alpha^{\prime}\right)\right. \\
& \left.\left.+\sin \alpha^{\prime}\right\}\right] / \pi \cos ^{2}(\pi / 12) \ldots \ldots \ldots \ldots(33)
\end{aligned}
$$

以上の解式で， $I_{f d d}, I_{k d}, I_{k q}$ を $\alpha^{\prime}, u, I_{L^{\prime}}$ の関数と して求觉る，次の結果加得られる。

$$
\begin{aligned}
\dot{x}_{a k d} & I_{k d} \\
= & X_{k d^{\prime}} I_{L}^{\prime}\left[F_{d^{\prime}} A_{c}-G_{d}\{2 \sin (\pi / 12)\right. \\
& \left.\left.+\mu B_{s^{\prime}}\right\}\right] / 2 E^{\prime}+18 X_{k d^{\prime}} X_{k q} I_{L}^{\prime} \\
& \times\left[\left(F_{q^{\prime}} G_{d}-F_{d^{\prime}} G_{q}\right) A_{s}+\left(F_{d^{\prime}} H_{q}\right.\right. \\
& \left.-F_{q}^{\prime} H_{d}\right) A_{c}+\left(G_{q} H_{d}-G_{d} H_{q}\right) \\
& \left.\times\left\{2 \sin (\pi / 12)+\mu B_{s}^{\prime}\right\}\right] / \pi\left(x_{d^{\prime \prime}}\right. \\
& \left.+x_{q}^{\prime \prime}\right) E^{\prime} \\
x_{a f d} & I_{f d d}+x_{a^{\prime} k d} I_{k d} \\
= & X_{k q} I_{L}^{\prime}\left(H_{q}\left\{2 \sin (\pi / 12)+\mu B_{s}^{\prime}\right\}\right. \\
& \left.-F_{q} A_{s}\right] / 2 E^{\prime}+\pi\left(x_{d}^{\prime \prime}+x_{q}^{\prime \prime}\right) I_{L}{ }^{\prime} \\
& \times\left\{2 \sin (\pi / 12)+\mu B_{s}^{\prime}\right\} / 72 E^{\prime} \\
x_{a k q} & I_{k q} \\
= & X_{k q} I_{L^{\prime}}\left[F_{q}^{\prime} A_{c}-G_{q}\{2 \sin (\pi / 12)\right. \\
& \left.+\mu B_{s^{\prime}}^{\prime}\right] / 2 E^{\prime}
\end{aligned}
$$

但し,

$$
\begin{aligned}
& A_{c}=\cos \alpha^{\prime}-\cos \left(u+\alpha^{\prime}\right) \\
& A_{s}=\sin \alpha^{\prime}-\sin \left(u+\alpha^{\prime}\right) \\
& B_{s}^{\prime}=\sin 2\left(\alpha^{\prime}+\pi / 24\right)-\sin 2\left(u+\alpha^{\prime}-\pi / 24\right) \\
& E^{\prime}=\sqrt{3}\left\{\frac{\pi}{36} A_{c}-\frac{X_{k q}\left(G_{q}^{\prime} A_{s}-H_{q} A_{c}\right)}{x_{d^{\prime \prime}}+x_{q}^{\prime \prime}}\right\}
\end{aligned}
$$

また, $F_{d}^{\prime}, F_{q}^{\prime}$ は付録に示す関数であり, $G_{d}, G_{q}, H_{d}$, $H_{q}$ は文嗝 (10)の付録と同じ関数である。

\section{5. 推移角之順, 逆変換境界点弧角}

サイリスタの代りにダイオードを使用したときの 自然点砤時の $\alpha^{\prime}$ (推移角)，を $\alpha_{n}^{\prime}$ で表すと， $\alpha_{n}{ }^{\prime}$ は $P_{\theta} \eta^{\prime}(0)=0$ を満すすのとなり，次式が成立する〔P $P_{\theta} \eta^{\prime}$ は(25)式より求まるう。

$$
\begin{aligned}
&\left(x_{a f d} I_{f d d}+x_{a k d} I_{k d}\right) \tan \alpha_{n}^{\prime}-x_{a k q} I_{k q} \\
&=\left\{-\mu\left(x_{d}{ }^{\prime \prime}+x_{q}{ }^{\prime \prime}\right) I_{L}{ }^{\prime} \cos 2\left(\alpha_{n}^{\prime}\right.\right. \\
&+\pi / 24)\} / \sqrt{3} \cos \alpha_{n}^{\prime} \ldots \ldots \ldots \ldots \ldots
\end{aligned}
$$

徉って，(34)式中の $\alpha^{\prime} を \alpha_{n}{ }^{\prime}$ と捄いて，上式を满足 する $\alpha_{n}{ }^{\prime}$ を反覆計算により求めることができる。

屰変換動作可能な $\alpha^{\prime}$ の限界 $\alpha_{e}^{\prime}$ は，サイリス夕の ターンオフ時間を無視すると，(32)式の $v_{x}(u)$ が雾と なることにより求まり，同一の $I_{L} / I_{f d d}$ に対して，逆 変換動作時の推移角 $\pi-\alpha e^{\prime}$ などについて，文献 $(10)$ 之同じく次式が成立する。

$$
\left.\begin{array}{l}
\left.u\right|_{\alpha^{\prime}=\alpha_{e^{\prime}}=u \mid \alpha^{\prime}=\alpha_{n^{\prime}}} \\
\left.\left(\bar{v}_{L} / I_{f d d}\right)\right|_{\alpha^{\prime}=\alpha_{\theta^{\prime}}}=-\left.\left(\bar{v}_{L} / I_{f d d}\right)\right|_{\alpha^{\prime}=\alpha_{n}^{\prime}} \\
\pi-\alpha_{e^{\prime}}=u+\alpha_{n}^{\prime}
\end{array}\right\}
$$

順，逆変換動作の境界点弧角 $\alpha_{b}{ }^{\prime}$ は，(33) 式の $\bar{v}_{L}$ $=0$ を満すむのであり，重なり角 $u$ との間に文献 $(10)$ と同じ次式が成立する。

$$
\pi / 2-\alpha_{b}^{\prime}=u / 2
$$

\section{6. 結合リアクトル容量}

本方式において，相間りアクトルは無いが三相結合 リアクトルを使用して扣り，その容量が問題になる (この場合 $i_{L 1} \neq i_{L 2}$ であるので相間リアクトルを設け てはならない)。

(24) 式の巻線 $N_{u 1}$ の電王 $v_{n u 1}$ は, 同一の $\alpha^{\prime}$ 亿対 しては $I_{L}$ が小さいほど大となる。 $I_{L} \fallingdotseq 0$ で $i_{k d,}, i_{k q}$ $i_{f d}, u$ 住何机も零になり， $v_{n u 1}$ は次式で表される。

$$
\begin{aligned}
v_{n u 1}= & x_{a f d} I_{f d d}[\tan (\pi / 12) \cos \{(5 m \\
& -1 / 2) \pi / 6\} \cos \left(\theta^{\prime \prime}+\alpha^{\prime}-\pi / 12\right) \\
& -\cos \{(5 m-1) \pi / 6\} \sin \left(\theta^{\prime \prime}\right. \\
& \left.\left.+\alpha^{\prime}\right)\right] / \cos (\pi / 12) \ldots \ldots \ldots \ldots \ldots \ldots \ldots
\end{aligned}
$$

第 3 図に $\alpha^{\prime}=\pi / 4$ の場合の乙れの波形を例示する。

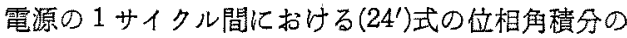
全振瀜を $\Phi_{R}$ とすると， $\Phi_{R}=\left(\right.$ 巻線 $N_{u 1}$ の磁束鎖交数 の全振幅)/ $/ \omega$ となる。相電压を定格とするリアクトル 巻線の位相角積分の全振幅を $\Phi_{P}$ とすると， $\Phi_{P}=2$ $x_{a f d} I_{f d d} / \omega$ である。発電機は六相巻線となっており， 三相結合リアクトルの $M_{4}$ 脚には $n$ 巻の巻線 $N_{u 1}$ の 他に $n / \sqrt{3}$ 巻の巻線 $N_{v 22}$ と $N_{u 21}$ がある。よって 変纴器の容量を(巻線容量の総計) $/ 2$ で定䣡すると，こ の結合リアクトルの変圧器に換算した等価容量の同期 機容量に対する割合 $P_{c}$ は次式で表わされる。

$$
P_{c}=\left\{3(1+2 / \sqrt{3}) \Phi_{R} / 6 \Phi_{P}\right\} / 2
$$

この値を各 $\alpha^{\prime}$ に対して嘼算して第 4 图に示す。

第 4 図より， $P_{c} \mid \alpha^{\prime}=30^{\circ}=7.2 \%$ であり，Pcの最大 


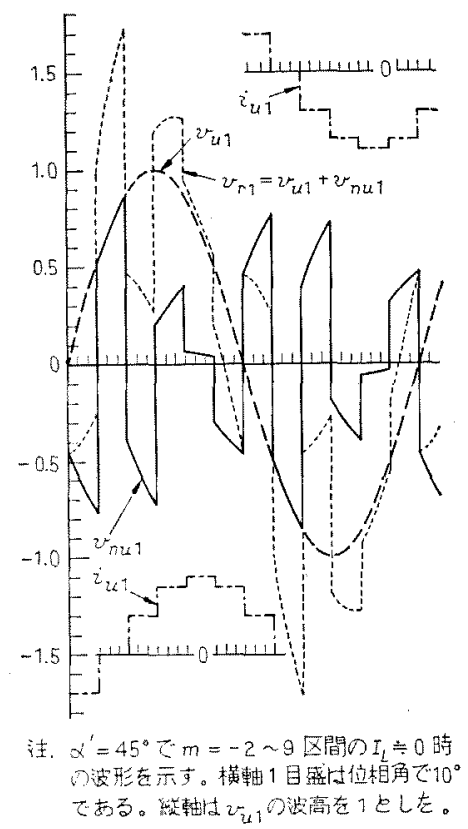

第 3 园 三相結合リアクトル巻線の電生 波形の一例

Fig. 3. An example of voltage waveforms of the three-phase coupling reactor windings.

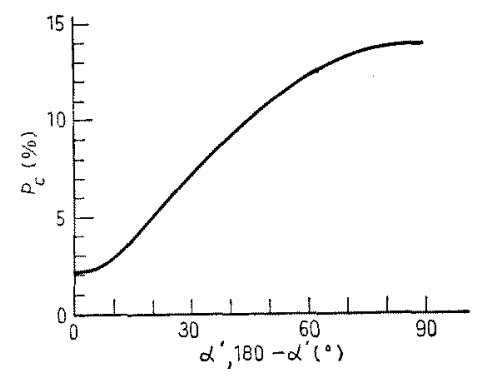

第 4 図 制御角之同期機に対する三相結合 リアクトルの容量比の関係

Fig. 4. Relation between firing angle and capacity ratio of three-phase coupling reactor to synchronous machine.

值は $P_{c} \mid \alpha^{\prime}=90^{\circ}=14.0 \%$ となる。これは相間りアクト ルを使用した場合の相間リアクトル容量の6 倍弱にな る。但し，相間リアクトルには電流波形の改善作用が なく，また，Rec. 1 と Rec. 2 の平均喤流電王の不平 衡を禣償できないので 2 組の三相巻線電流相互間の不 平衡を袢償する作用がない。

\section{6 パルス整流器負荷三相同期機との比較}

上述の解析結果を用いて，文献(10)の6パルス整流
第 1 表 供試同期機の定数

Table 1. Constants of the tested machines.

\begin{tabular}{|c|c|c|c|c|}
\hline 定 数 機 梠 & $N$ & $D$ & $Q$ & $D Q$ \\
\hline$x_{l}+3 x_{a d} \quad(\Omega)$ & 27.1 & 27.1 & 27.1 & 27.1 \\
\hline$x_{1}+3 x_{a q} \quad(\Omega)$ & 27.1 & 27.1 & 27.1 & 27.1 \\
\hline$(\Omega)$ & 5000 & 1410 & 5000 & 1410 \\
\hline$(\Omega)$ & - & - & 344 & 344 \\
\hline$x_{a f d} \quad(\Omega)$ & 106 & 106 & 106 & 106 \\
\hline$x_{a k g}$ & - & - & 52.8 & 52.8 \\
\hline$K_{f d}$ & 0.0212 & 0.0752 & 0.0212 & 0.0752 \\
\hline$K_{k q}$ & - & - & 0.154 & 0.154 \\
\hline$X_{k d}^{\prime}$ & 2.25 & 7. 97 & 2. 25 & 7.97 \\
\hline$X_{k q}$ & - & - & 8.10 & 8.10 \\
\hline$(\Omega)$ & 20.4 & 3.19 & 20.4 & 3.19 \\
\hline$(\Omega)$ & 27.1 & 27.1 & 2.79 & 2.79 \\
\hline$\mu$ & -0.142 & -0.789 & 0.759 & 0.0679 \\
\hline
\end{tabular}

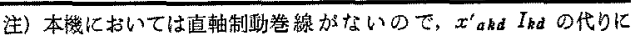

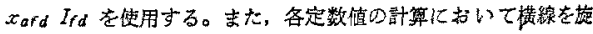
した定数を含む項は答とする。

器負荷三相同期譏上の特性比較を行なう。

$\langle 7.1\rangle$ 供試機文献(10)の供試機の三相巻線を 2 分割して三相二重巻楾にして測定した諸定数を第 1 表に示す。本表において，記号 $N, D, Q, D Q$ の意 味は文苚(10)に詳述したように，制動巻線なし，直軸 制動巻線付，橫軸制動巻線付掞よび画螒制動巻線付に 対応するあのである。

$\langle 7.2\rangle$ 特性比較 第 5 図 第 9 図に文竬 (10)K 対比する諸特性を示す。本稿では，文献(10)のある動 作点に，負荷電流が 2 倍で負荷電圧が半分の点が対芯

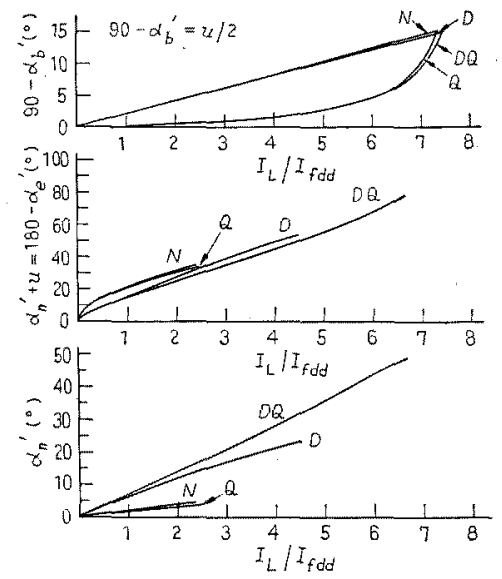

第 5 図 負荷電流と推移角 $\left(\alpha_{n}^{\prime}, 180^{\circ}-\alpha_{\varepsilon}{ }^{\prime}\right)$ の関係

Fig. 5. Relations between load current and displacement angles $\left(\alpha_{n}{ }^{\prime}, 180^{\circ}-\alpha_{e}{ }^{\prime}\right)$. 


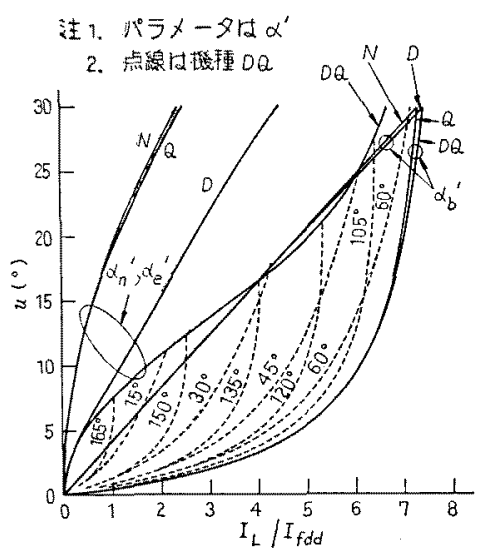

第 6 困負荷電流と転流重なり角の関係

Fig. 6. Relations between load current and commutating overlap angle.

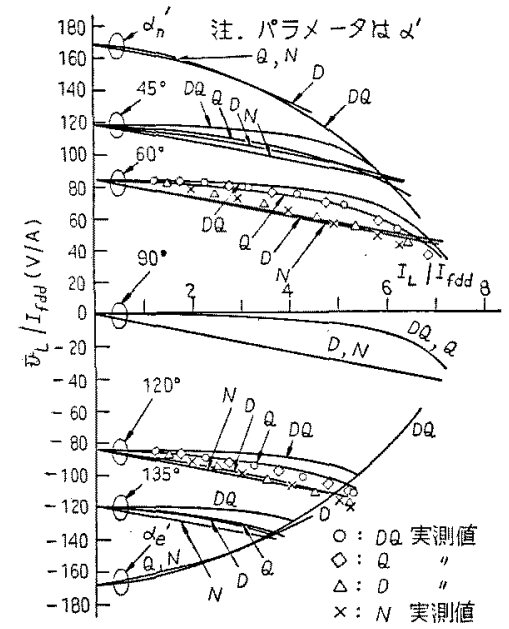

第 7 图, 真荷電流亡平均負荷電圧の関係

Fig. 7. Relations between load current and mean load voltage.

することになるので，目盛幅を $I_{L} / I_{f d d}$ は文献 (10)の 半分に， $\bar{v}_{L} / I_{f d d}$ 结 2 倍にしている。また，文献(10) の電気角 $\pi / 3$ に本稿の $\pi / 6$ が対忍している。

横軸制動巻線が特性改善に有効であることは，文献 (10) 之同様である。第 9 四之文献(10)の第 7 図を比較 すれ代，制動巻線電流の周波数は 2 倍に，その大きさ は約半分になって扝り，これによる擅失が非常に小さ くなることがわかる。

第 8 図と文献 $(10)$ の第6 図を比較す机ば，トルク脤 動 ( $v_{L}$ の脈動) は，その周波数が 2 倍になるばかりで なく，その大きさが半減している。

また，文献 (10)の第 5 図と本稿の第 7 図を比較して わかるように，順変换領域（発電機動作領域）に扔い ては電圧変動率が非常に小さくなっている。逆変換領

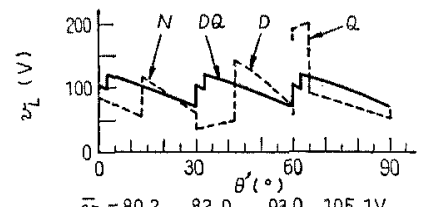

$\bar{v}_{L}=80.2,82.0,93.0,105.1$

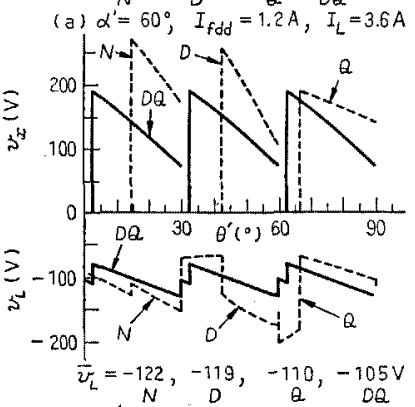

(b) $\alpha^{\prime}=120^{\circ}, \quad I_{\text {fdd }}=1.2 \mathrm{~A}, I_{L}=3.6 \mathrm{~A}$

第 8 図 負荷電压とサイリス夕逆電圧の波形

Fig. 8. Waveforms of load voltages and thyristor reverse voltages.
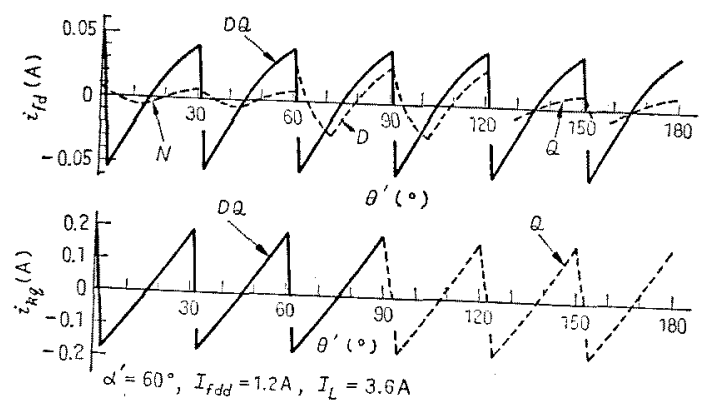

第 9 図 制動巻線電流波形

Fig. 9. Damper-winding current waveforms.

域（電動機動作領域）においては，直流電流一電王特 生の平滑化により同一動作点に対応する $180^{\circ}-\alpha^{\prime}$ が 小になり，基本波の無效電力む低減されることになっ ている。更に， $\alpha^{\prime}=\alpha_{e}^{\prime}$ の曲線在対比してわかるよう に, 電動機の出力限界が増大していることがわかる。 てれは，三相結合リアクトルが整流回路にお污る相間 リアクトルと同栐の特性改善作用をするととすに，高 調波成分の除去に上り転流時の電流変化を更に減少さ せ，同一動作点における重なり角 $u$ を $1 / 2$ より小さ くすることに起因している(文献(10)の第 4 図と本稿 の第6図を比較参照)。

これらの傾向は，通常の同期機についての特性計算 の比較によっても明りょうに認められる(11)。

$\langle 7 \cdot 3\rangle$ 実験結果 第 7 図に $I_{f d d}=1.2 \mathrm{~A}$ の場合 の $\alpha^{\prime}=60^{\circ}$ および $\alpha^{\prime}=120^{\circ}$ における実験結果をプロ ットする。実験は直流電源設備の関係で $30 \mathrm{~Hz}$ で行な 


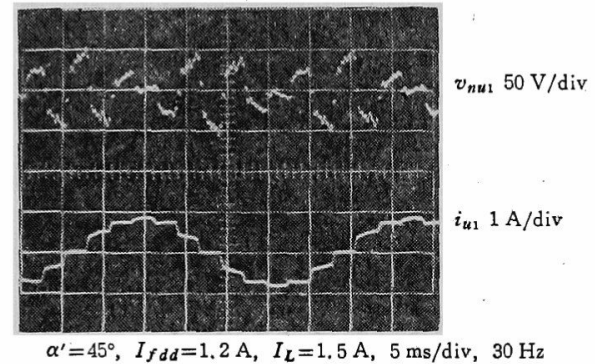

第 10 図 三相結合リアクトル巻線電圧と 相電流波形のオシログラム

Fig. 10. Oscillogram of three-phase coupling reactor winding voltage and phase current.

い $60 \mathrm{~Hz}$ に換算し，また， $\bar{v}_{L}$ の測定值にサイリスタ による電圧降下として $2.5 \mathrm{~V}$ を加減した。

第 10 図に第 3 図に対応するオシログラムを示す。 供試機が誘導機を改造したむのであるため, 出力電 王に多量の高調波成分を含み，また，磁気飽和による 定数変化があるので, 計算值と実測值の完全な一致は 得られていないが，本方式の特長は確認された。

\section{8.むすび}

以上，本方式が比較的小容量の結合リアクトルを使 用して 2 組の三相巻線の電流を平衡させ, 更に相電流 波形を改善するばかりでなく，文献(10)と同様な解析 により，従来の三相方式に比べて諸特性を大幅に改善 するあのであることを明らかにした。

第 7 図の $u=30^{\circ}$ に対応する $I_{L} / I_{f d d}$ の最大值を超 える範囲では自然発生点弧遅れおよび場合によっては 電流の二重重なりが生じるが，この範囲の解析につい ては後報する。

終りに, 常に御指導を頂いている九州大学工学部野 中作太郎教授研究室関係の方々に深謝致します。

(昭和 54 年 4 月 23 日受付)

\section{文献}

(1) 松本:「九相インバータ駆轩三相三重巻線交流電動機」電学 誌 $B ， 94 ， 415$ (昭 49-9)

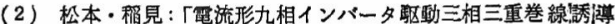
電動機」昭50電気四学会九州支部連大 No. 118

（3）松本・稻見：「波形改良用結合リアクトル付の整流器負荷同 期機之電流形ヘンパータ」昭51電気学会全大 No. 684

(4) T. J. Takeuchi: Matrix Theory of Electrical Machinery (オーム社)

（5）松本：「三相多電模成の多相インパータおよび多相整流回路 の交流電流波形改良用結合リアクトル」昭49電気学会全大 No. 456

（6）松本：「波形改良用結合リアクトルによる十二相变換回路の 特性解析」昭 49 電気関係学会四国支部連大 No. 9-2

（7）松本・榴見：「整流器負荷を持つ三相二重巻線同期発電機の 特性解析」新居兵工業息等専門学校粑要 (理工学編) 12，37 (昭 51-1)

（8）高檽: 「高調波電流負荷(整流器負荷など)の同期機に及ほす 影旂」電学誌，93，491 (晒 48-6)

（9）宇高・甲藤・赤松：「多相形サイリスタモータにおけるトル ク眼動の考察法」制御变換犆研究会資料 PCC-78-8 (昭 53-1)

（10）松本・稲見：「6 パルス整流器負荷三相同期機の解析」電学 綕 $\mathrm{B}, 99,137$ (昭 54-3)

（11）松本・馡見 : $\lceil 12$ パルス整流器負荷三相二重巻線同期機の特 性」昭52電気学会全大 No. 733

\section{付 録}

(27)式の右边の計算結果になる(34)式中で使用した 文献 (10) と異なる関数の定義式を次に示す。

$$
\begin{aligned}
F_{d^{\prime}}= & -2 \sin (\pi / 12) \sin \left(u+\alpha^{\prime}\right) \\
& +\mu \int_{\alpha^{\prime}}^{\mu+\alpha^{\prime}} \frac{\sin 2(\varphi+\pi / 24)}{1+\mu} * \\
* & \frac{-\sin 2\left(\alpha^{\prime}+\pi / 24\right)}{\times \cos 2 \varphi} \cos \varphi d \varphi \\
= & \cos \left(\alpha^{\prime}+\pi / 12\right)-\cos \left(u+\alpha^{\prime}-\pi / 12\right) \\
& -\left\{\sin (\pi / 12)+\mu \sin 2\left(\alpha^{\prime}+\pi / 24\right)\right\} f_{s} \\
& +(1-\mu) f_{c} \cos (\pi / 12) \\
F_{q^{\prime}}= & 2 \sin (\pi / 12) \cos \left(u+\alpha^{\prime}\right) \\
& +\mu \int_{\alpha^{\prime}}^{\mu+\alpha^{\prime}} \frac{\sin 2(\varphi+\pi / 24)}{1+\mu} * \\
* & \frac{\sin 2\left(\alpha^{\prime}+\pi / 24\right)}{\times \cos 2 \varphi} \times \sin \varphi d \varphi \\
= & \sin \left(\alpha^{\prime}+\pi / 12\right)-\sin \left(u+\alpha^{\prime}-\pi / 12\right) \\
& +\left\{\sin (\pi / 12)+\mu \sin 2\left(\alpha^{\prime}+\pi / 24\right)\right\} f_{\sigma} \\
& +(1+\mu) f s \cos (\pi / 12)
\end{aligned}
$$

ここで, $f_{s}, f_{c}, f_{t}$ は文献(10) と同じ表現式である。 